\title{
The Use of EGRA Technique in Teaching Passive Voice in EFL Classroom
}

\author{
Siti Zaenap
}

Hamzanwadi University, Indonesia

Correspondence: Siti Zaenap, Indonesia. E-mail: b.2014sttaofik@gmail.com

Received: Novemebr 27, 2018

doi: 10.29408/veles.v3i1.1019.g732
Accepted: February 16, $2019 \quad$ Online Published: April 15, 2019

URL: http://dx.doi.org/10.29408/veles.v3i1.1019.g732

\begin{abstract}
This study aimed at investigating the effectiveness of experience, generalization, reinforcement, and application (EGRA) technique in teaching passive voice of EFL learners. The design of this study was pre-experimental research with pre-test and post-test design. It was conducted at the EFL students of Hamzanwadi University especially in the second semester of English department in the academic year 2017-2018. The sample consisted of 28 students. In determining the sample, this study used cluster random sampling technique. The instrument was objective test in form of multiple choices in order to collect the data. The data was analyzed by using descriptive statistic and paired sample t-test in order to test the hypothesis. The result of descriptive statistic indicated EGRA technique is effective for EFL learners on which the mean score of post-test (14.21) was greater than the mean score of pretest (9.96). For the hypothesis testing by using paired sample t-test at significance ( 2 tailed) value level of analyzed data was .000 , it was lower than 0.05 . So, it indicated that the alternative hypothesis of this study was accepted. In other word, EGRA technique was significantly effective in enhancing students' ability in passive voice at the second semester of Hamzanwadi University in the academic year 2017-2018.
\end{abstract}

Keywords: EGRA Technique, simple present tense, passive voice

\section{Introduction}

Nowadays, English is a language which is used in international event as a medium of information flow on science, technology, and culture. Because of the reason, we are a developing country-should try to be able to master English both in spoken and in written form in order to be able to build relationship with other people of other countries in the world so that we could transfer and master the sciences and technologies in those countries.

As we know that Indonesian tends to spend more time to learn English as a foreign language. It is settled as the compulsory subject at several school levels such as: Elementary school, Secondary school and University. In fact, English language settles four skills that should be mastered namely: listening, speaking, reading, and writing but in mastering those skills people minimally should have basic knowledge about the components of those language 
those are: pronunciation, phonology, grammar, and vocabulary. In this case, the present researcher is going to examine one of those elements; that is grammar especially related to passive voice.

Passive voice is one of the most common forms in English structure. According to Cambridge Dictionary, "passive voice is the relationship between a subject and a verb which the subject receives the action of the verb, or the verb forms show this relationship". The function of passive voice is to show another idea of the active sentence which focuses on the subject who receives the action or it emphasizes the recipient of the action

Even passive voice is important but in the reality many English teachers commonly found the barrier in teaching it. However according to the previous researchers, Ratna, et al., (2016) reported that many learners have difficulty in applying passive voice rules even in creating a simplest sentence, although these have been taught intensively. Another problem is the teachers often do not implement an interesting and attractive method to attract students' attention in teaching passive voice and it obviously makes the students subconsciously thinks that grammar especially passive voice is a frightening subject to be learnt.

To overcome those problems, the teachers can apply one of the various suitable techniques, strategies, or methods that meet students' characteristic. Here, the present researcher applied experience, generalization, reinforcement, and application (EGRA) technique which was really recommended for English teacher in teaching simple present tense in passive voice.

According Sari (2017, p. 32) "EGRA is an example of grammar presentation technique which focuses on students' active discovery approach.” This technique has four stages which each stage has their own rules in applying it. EGRA is shortened form of the term Experience, Generalization, Reinforcement, and Application. Experience is a learning stage where the students are subconsciously exposed to meaningful use of a particular structure item. At this stage, the teacher begins the class by asking the students some leading questions related to the material that is going to be taught. Generalization is a learning stage where the students cooperate to find the form and function of passive voice. At this stage, the students are led through task to discover form, meaning, and function of passive voice. The teacher does not need to correct students' answer, letting their creativity freely to express their ideas. Reinforcement is a learning stage where the teacher attempts to correct or revise the students' conclusion in generalization phase. After that the students do task again to check their understanding. At this stage, the students will do tasks again as strengthening their understanding. Application is a learning stage where the students must use the form of passive voice that they had learned. At this stage, the students are expected to be able to apply the pattern of simple present tense in passive form in real situation.

Based on the explanation above, the researcher conducted a study in teaching grammar especially Passive Voice at EFL university students through EGRA technique in the academic year 2017-2018 in order to help the students to produce correct simple present tense in passive form. The present researcher applied EGRA technique in teaching grammar subject to give them opportunity in grammar skill. 


\section{Method}

In this study, the researcher applied experimental design. According to Ary (2010, p. 301), an "experimental design is the general plan for carrying out a study with an active independent variable." He also states that a design is important because it determines the study's internal validity, which is the ability to reach valid conclusions about the effect of experimental treatment on the dependent variable. One of the experimental designs is preexperimental.

The method used was pre - experimental method with one group pre-test and post-test design. One group pre-test and post-test design is a single case which observes at two time points, one before the treatment and one after the treatment.

\subsection{Participants}

The population of the study was the second semester of Hamzanwadi University students in the academic year 2017-2018. The number of students in the second semester was 107 and was separated into three classes. The sample of this study was the $\mathrm{C}$ class of the second semester of English department which consisted of 28 students. The technique of sampling that the researcher applied was cluster random sampling. Basically, the present researcher did selection of the samples by using lottery.

\subsection{Data Collection}

\subsubsection{Instrument of Collecting Data}

This study used test as instrument for getting the data. In this study the researcher used objective test in form of multiple choice to measure the students' ability. The number of items after getting try out was 19 items which the score for the correct answer was 1 and the score was 0 for false answer. Thus, in this study the maximum score was 19 and the minimum score was 0 .

\subsubsection{Techniques for Collecting Data}

In collecting the data, the present researcher took the data from conducting pre-test and post-test. The pre-test was given to the subject before treatment. Meanwhile, post-test was given after conducting treatment. In treatment the researcher applied EGRA technique to teach grammar of passive voice (simple present tense). The treatment was done in four meetings.

\section{a. Pre test}

The pre-test was given before the researcher gave treatment by using EGRA technique in simple past tense. It measured the degree of the students' score before treatment. The pre-test firstly was conducted on Monday, 23rd of April 2018. The number of students who joined pre-test was 28. After collecting the data, the present researcher calculated the score of students. The students' score of pre test was 53 which was categorized into "modest"

\section{b. Treatment}

After conducting pre-test the researcher treated the students by using EGRA technique. The teaching process was begun on Thursday, 26th of April 2018. Here, the students were 
given four steps in teaching passive voice especially in simple present tense form. In experience stage, each student was given a text which some sentences were in form of passive voice. Students were asked to find out what they were confused about. Then, in generalization stage, students were asked to work in group which each group consisted of 5 people. Here, the teacher gave a topic that was discussed by each group. Every group had their own understanding about the topic given and the result was absolutely presented. Other group had time to respond or deliver either their opposite or similar idea about each group presentation. Teacher allowed students to discuss freely but constantly under the instruction of teacher. In reinforcement stage, students were provided the explanations about what they confused about in experience stage and generalization stage. In addition, Teacher gave a brief example as well to strengthen students' understanding. The last stage would be application, here students were asked to work individually to answer a task given to see their understanding.

The second meeting was conducted on Monday, 30th of April 2018. There was a little difference between first and second meeting that was in the topic. In the first meeting was about the meaning, form, and function of passive voice. On the other hand, the topic of the second meeting was about direct indirect object and transitive and intransitive verb.

The third meeting was done at the third of May 2018; meanwhile the forth meeting was conducted at the 7th of May. In experience stage students were provided long text in order to find out the passive form of simple present tense individually. In generalization stage, students were obligated to work in pair to discuss and analyze it. In reinforcement, teacher just acted as mediator and teacher only clarified what should be clarified. Those activities were done in four meetings from 26th of April till 7th of May.

c. Post-test

Post test conducted after conducting treatment by using EGRA technique. This aimed to know the students' score in passive voice. Post-test was conducted on Friday, 11th of May 2018. Here, students were given the same test that was given in the beginning. After collecting and calculating the data, students' score was 75 which categorized into "High."

\subsection{Data Analysis}

\subsubsection{Descriptive statistics}

The data of this study was collected and analyzed by using descriptive statistic. Descriptive statistics was used to find out the main and standard deviation. For these purposes, the present research performed Frequencies by using IBM SPSS 22 for windows.

\subsubsection{Required statistic for testing hypothesis}

\section{a. Normality}

Normality test was used to find out whether the data distributes normally or not. According to Bhuono (2005, p. 18) "a good and proper data to be used in a research is the data that has normal distribution". For this purpose, to know whether the data is normal or not; the present researcher used Shapiro-wilk in SPSS 22 for windows.

\section{b. Homogeneity}

Homogeneity was used to find out whether the data was homogenous or not. In this matter, the present researcher used One-Way ANOVA Test in SPSS 22 for windows. 


\section{c. Testing hypothesis}

The result of the data that was analyzed after the researcher compared the result of pretest and posttest. Furthermore, the researcher used Paired Simple T Test in SPSS 22 for windows to analyze the hypothesis testing in aiming to know whether the alternative hypothesis was accepted or not.

\section{Findings}

According to the data of pretest which was obtained from 28 students of the second semester in English department, the present researcher found that the students' ability in grammar regarded as "modest" and it could be seen from the gained data of mean score (9.96) which was categorized into modest. . The detail data that was classified regarding to the students' result in pre-test was as follows: 9 students (32\%) was categorized into "high", 11 students (39) was categorized into "modest", 7 students $(25 \%)$ was categorized into "low", and 1 student (4\%) was categorized into "very low". Hence, based on the data above it can be assumed that $53 \%$ of the students categorized into "modest" still had problems and were crucially aided to enhance their ability in grammar.

In addition, the result of post-test showed that the students' ability was significantly enhanced, it can be proved by the mean score (14.21) which was categorizes into "high". The detail data concerning the students' achievement in post-test can be shown as follows: 10 students (35\%) assorted into "very high", 13 students (43\%) assorted into "high", 6 students (21\%) assorted into "modest". Hence, from the data above it shows that $75 \%$ of students' grammar ability categorized into "high" it meant students' ability in grammar especially in passive voice was getting increased.

Furthermore, the result of the calculated data demonstrated that the mean score of experimental group in pre-test was 9.96 while in post-test was 14.21. Besides, the standard deviation of pre-test was 3.46 while in post-test was 3.02. Related to the obtained data of the students in passive voice, it pointed that the students' grammar ability were increased if it compared with the value of the mean score in pre-test and post-test, in which the mean score of post-test was higher than pre-test.

This kind of test was utilized to know whether the null hypothesis $\left(\mathrm{h}_{0}\right)$ wasaccepted or rejected. To analyze whether there was significant difference in the mean score between the pre-test and post-test, the present researcher used a paired sample t-test to get answer of the hypothesis. The present researcher found that there was a significant difference in the mean scores between the pre-test and post-test, $\mathrm{t}(\mathrm{df}=27)=34.84$ at $\mathrm{p}<.01$, implying that there was EGRA (experience, generalization, reinforcement, and application) was significantly effective in teaching grammar especially passive voice at the second semester of EFL university students.

\section{Discussion}

The purpose of this study was to find out the effectiveness of experience, generalization, reinforcement, and application (EGRA) technique in teaching passive voice to the EFL 
learners and how was the effectiveness of experience, generalization, reinforcement, and application (EGRA) technique in teaching passive voice (simple present tense) to the EFL learners. The result of this study disclosed that EGRA technique was suitable to be used for teaching grammar to EFL learners. It gave impact to the success o the teaching and learning process. In this matter, EGRA technique gradually encouraged the students to be more aggressive unconsciously in acquiring their understanding with paying attention to the teacher's instruction. During the treatment process, in whole stages the students were excited to discover their knowledge and do some tasks without ignoring the instructions. Furthermore, EGRA technique built cooperative relationships among EFL students. It gave the students chance to work and overcome the problems in group.

In addition, during EGRA technique steps, students of each group were demanded to understand what had been instructed then they presented their result in front of other groups and the result being responded by other groups. It perfectly built students' confidence and built their eager to maintain their ideas. In EGRA activities, the step that pressured was in generalization phase. Beside, in this stage students were allowed to discuss in finding and solving the problems provided. The students totally made the conclusion by their own understanding and conveyed it briefly without any correction from the teacher. Unconsciously in this stage, the representative student of each groups built a communicative discussion with other groups while they were delivering their result. Positively, the students have their own understanding and explanation of the topic given and it encouraged the other groups to deliver their opposite ideas.

Additionally, after finishing discussion, the teacher took time to clarify what the students' confusing about in the discussion by elaborating and providing some instances. This stage was reinforcement. Generally, after conducting discussion, a lot of the students did not have good understanding in passive voice even it was taught in the previous semester. That is why; the teacher provided the students brief examples of how to arrange the correct sentences of passive voice in simple present tense.

Briefly, in application stage conducted after reinforcement. So, in this stage students were given a task with producing their own sentence in order to strengthen their understanding. Basically, by analyzing students' result in pre-test they still had problems not only in arranging the sentence by its form but also in using past participle verb. But the students gave a significant progress on building and analyzing the error questions.

The result of this research was supported with another research about EGRA technique, Syahana, A. Dahlan Raisam, and Dewi Sri Wahyuni (2012) reported her research result that EGRA technique is recommended to apply in teaching grammar. Based on the result, the value of pretest lower $(68.8 \%)$ than posttest $(91.8 \%)$ its mean that null hypothesis was rejected and the alternative hypothesis was accepted. In this research, the hypothesis is "EGRA technique was a significantly effective in teaching passive voice for the second semester of EFL university students. To support the result, brown (1993, p. 351) says that "it built more intrinsic motivation by allowing the students to discover rules rather than being told them" 
The results and discussion above have revealed that those students' grammar ability increased after conducting this teaching learning process using EGRA technique. They showed their better understanding in analyzing error question that given.

\section{Conclusions}

Based on the results, the present researcher could conclude that the experience, generalization, reinforcement, and application (EGRA) technique was significantly effective especially for the second semester of EFL university students. The value of post-test was higher than the value of pre-test. It assumed that the standard deviation and mean score were significant. The present researcher concluded that the students were being improved after getting treatment.

After processing the data, the researcher concluded that there was an effectiveness of experience, generalization, reinforcement, and application (EGRA) technique on students' grammar ability for the second semester of EFL university students. It was known because there was a significant difference between mean score of pre-test and mean score of post-test.

\section{References}

Ary, D., Jacobs, C. L., Sorensen, C.,\&Razavieh, A. (2010).Introduction to research education. London: Wardswoth. Cengange Learning.

Bhuono, A.N.,(2005). Strategi jitu memilih metode statistic penelitian dengan SPSS. Semarang: CV ANDI OFFSET.

Brown, H. D.(1980). Principles of language learning and teaching. Prentice-Hall, Inc, Englewood Cliffs, New Jersey: The United States of America.

Moedjito.(2016). Basic statistic for research in language education. Surakarta: Yuma Pustaka.

Ratna.Ferry, R. \&Zarkiani, H. (2014).Teaching passive voice the grade $x$ through egra technique at smanegri 5 palu, Indonesia. e-journal of English Language Teaching Society (ELTS), 4, 2331-1841.

Sari, Murhafah. (2017) The implementation of EGRA in improving students' ability in comprehending recount text at MTSN Hamparan Perak. Retrieved January, $12^{\text {th }} 2018$, 06.00pm, from http://repository.uinsu.ac.id/2666/ 